\title{
A CHECKLIST FOR ASSESSING SUSTAINABILITY PERFORMANCE OF CONSTRUCTION PROJECTS
}

\author{
Li-Yin Shen ${ }^{1}$, Jian Li Hao ${ }^{2}$, Vivian Wing-Yan Tam ${ }^{3}$ and Hong Yao ${ }^{4}$ \\ ${ }^{1,2,4}$ Dept of Building and Real Estate, The Hong Kong Polytechnic University, Hong Kong \\ ${ }^{3}$ Griffith School of Engineering, Griffith University, Australia \\ E-mail:v.tam@griffith.edu.au \\ Received 18 May 2007; accepted 01 Aug 2007
}

\begin{abstract}
Construction sustainability performance is indispensable to the attainment of sustainable development. Various techniques and management skills have previously been developed to help improving sustainable performance from implementing construction projects. However, these techniques seem not being effectively implemented due to the fragmentation and poor coordination among various construction participants. There is a lack of consistency and holistic methods to help participants implementing sustainable construction practice at various stages of project realisation. This paper develops a framework of sustainability performance checklist to help understanding the major factors affecting a project sustainability performance across its life cycle. This framework enables all project parties to assess the project sustainability performance in a consistent and holistic way, thus improving the cooperation among all parties to attain satisfactory project sustainability performance.
\end{abstract}

Keywords: sustainable development; construction, checklist, project sustainability performance, project life cycle.

\section{Introduction}

Previous studies have shown that construction industry and its activities have significant effects on the environment [1-5]. Sustainability performance of an individual construction project across its life cycle is an indispensable aspect in attaining the goal of sustainable development. Reports by the World Commission on Environment and Development [6] defined sustainable development as meeting the basic needs of the public and satisfying their aspirations for a better life without compromising the ability of future generations. Emphasis of this definition is placed on the balance among social development, economic development, and environmental sustainability. By adopting this conception, the impacts of construction activities on sustainable development can be considered in 3 main aspects: social, economic, and environmental. Adverse environmental effects from construction activities have been extensively addressed [7$11,5]$. These typically include energy consumption, dust and gas emission, noise pollution, waste generation, water discharge, misuse of water resources, land misuse and pollution, and consumption of non-renewable natural resources [12, 13]. Whilst there are various attributes contributing to sustainable construction practice, the environmental attribute has comprehensively been investigated. For instance, ISO 14000 series are introduced to provide a guideline to implement environmental management.

Appreciation of the significant impacts of construction activities on sustainable development has led to the development of various management approaches and methods to guide construction participants in achieving better project sustainability performance. Kibert's study [14] introduced 7 principles to implement sustainable construction practice, namely, (1) conserving (to minimise resource consumption); (2) reusing (to maximise the reuse of resources); (3) renewing/recycling (to use renewable or recyclable resources); (4) protecting the nature (to protect the natural environment); (5) using nontoxic materials to create a healthy, non-toxic environment; (6) economic benefits (to apply life cycle cost analysis); and (7) providing quality products. Hill and Bowen's study adopted 4 attributes to promote sustainable construction, including social, economic, biophysical, and technical aspects [15]. The social sustainability is to improve the quality of human life, to implement skills training and capacity enhancement of the disadvantaged, to seek fair or equitable distribution of construction social costs, and to seek intergenerational equity. The economic sustainability is to ensure financial affordability to the intended beneficiaries, to promote employment creation; to enhance competitiveness, to choose environmentally responsible suppliers and contractors, and to maintain capacity to meet the needs of future generations. The biophysical sustainability is to extract fossil fuels and minerals at rates which are not faster than their slow redeposit into the Earth's crust, to reduce the use of 4 generic resources (namely, energy, water, materials, and land); to maximise resource reuse and/or recycling; to use renewable resources in preference to non-renewable resources, to minimise air, land and water pollution, to maintain and to restore the Earth's vitality and ecological 
diversity; and to minimise damage to sensitive landscape. The technical sustainability is to construct durable, reliable, and functional structures; to pursue quality in creating built environment; to humanise large buildings; and to infill and to revitalise the existing urban infrastructure. Other studies presented methods to mitigate barriers in implementing environmental management in construction in order to achieve a better sustainability performance $[12,14,7,16-18]$.

However, fragmentation in using these principles cannot achieve satisfactory results. Different project participants often practice in isolation their management activities and emphasise their individual viewpoints. There is a lack of methodology to help all project participants working in a consistent and cooperative environment towards the same goal for achieving better project sustainability performance. A revolutionary solution is required to enable the integration of various methods and the working-together among all project participants. By establishing a framework of sustainability performance checklist, this paper presents a holistic and integrated research-based approach to consider the project sustainability performance. The development of this framework is largely based on conducting a comprehensive literature review. The checklist is developed from a holistic process across the project life cycle and enables all project participants to understand and contribute to the project sustainability performance.

\section{Research methodology}

The major objective of this study is to develop a project sustainability performance checklist that can be used by all project participants to understand and improve sustainability performance in the holistic process of the project life cycle. The data used for analysis are mainly from a comprehensive literature review. A preliminary list of sustainability performance factors was generated in the early research stage and this list was presented through interviews to the invited professionals for their comments. Interviews were invited and arranged with different project parties, including two governmental departments, 3 clients, 2 consultants, 4 contractors, 2 subcontractors and 1 supplier. These interview discussions provide valuable comments on the adequacy of the selection of the preliminary checklist, which were incorporated in the formulation of the final checklist. Teamorientated approach has been adopted throughout the study by engaging comprehensive discussions within the research team.

\section{Factors affecting project sustainability performance}

Factors affecting the sustainability performance of a construction project are different at various stages across project life cycle. Life cycle is widely adopted both in social and natural sciences, which is often used to represent maturational and generational processes driven by mechanisms of reproduction in natural population. In construction business, the Royal Institute of British Architects [19] defined the standard processes to operate construction projects, which include pre-design, design, preparing to building, construction, and post construction. In another typical description, the life cycle process of a construction project includes conception and feasibility studies, engineering and design, procurement, construction, start-up and implementation, and operation or utilisation. Ritz's study suggests the life cycle of construction projects, including conceptual phase, through project definition, execution, operation, and finally demolition [20]. According to "environmental code of practice for buildings and their services" published by the Building Services Research and Information Association [21], the life cycle of a construction project is divided into predesign, design, preparing to build, construction, occupation, refurbishment, and demolition. Kibert's study described a construction project life cycle as a process of planning, development, design, use, maintenance, and deconstruction [14]. Shen et al's study separated the process of a project life cycle into inception, design, construction, operation and demolition [7, 13]. Based on the review of these previous studies, 5 major processes are applied to compose a project life cycle, namely, inception, design, construction, operation and demolition. These 5 processes are examined for developing the project sustainability performance checklist in this study.

Sustainable development represents the sustainability of economic development, social development, and environmental development [6]. In line with this conception, factors affecting sustainability performance of a construction project can be examined in 3 main categories: economic sustainability factors (ESF), social sustainability factors (SSF), and environmental sustainability factors (EnSF). A framework of project sustainability factors is proposed in a matrix format as shown in Table 1.

Table 1. Framework of project sustainability performance factors

\begin{tabular}{l|l|l|l}
\hline \multirow{2}{*}{ Project stages } & \multicolumn{3}{|c}{ Project sustainability performance } \\
& factors \\
\cline { 2 - 4 } & ESF & SSF & EnSF \\
\hline I (Inception) & ESF-I & SSF-I & EnSF-I \\
\hline II (Design) & ESF-II & SSF-II & EnSF-II \\
\hline III (Construction) & ESF-III & SSF-III & EnSF-III \\
\hline IV (Operation) & ESF-IV & SSF-IV & EnSF-IV \\
\hline V (Demolition) & ESF-V & SSF-V & EnSF-V \\
\hline
\end{tabular}

Based on the literature review and interview discussions with the different project stakeholders, Table 2 presents the details of the project sustainability performance checklist.

\subsection{Inception stage}

The major objectives of inception stage are to comparatively investigate multi-scenarios about the necessity and possibility of investment, and to address the issues in such a way as why, when, and how to invest. This stage concerns opportunities study and preliminary feasibility study, which leads to investment decisions. Project pro- 
posal needs to be developed to demonstrate the necessity of project and possibility of procurement for project resources. These activities are essential to help project clients making decisions on whether they need to proceed forward with their work. The proposal for a potential project plays a critical role to affect the project's sustainability performance. The principle of good project sus- tainability performance should be incorporated into the project proposal. Project feasibility studies should be in line with the principles of sustainable development, thus to investigate and to analyse the feasibility of project conditions on various aspects including engineering, technology, social aspect, economic benefits, and environmental effects.

Table 2. Project sustainability performance checklist across project life cycle

\begin{tabular}{|c|c|}
\hline \multicolumn{2}{|l|}{ Project inception stage } \\
\hline \multicolumn{2}{|l|}{ ESF-I } \\
\hline Supply and demand & $\begin{array}{l}\text { Evaluating local, regional, national, and even global market supply and demand of current } \\
\text { similar products/projects and in the future }\end{array}$ \\
\hline Marketing forecast & Predicting market size, pricing, marketing strategies, and marketing targets \\
\hline Scale and business scope & $\begin{array}{l}\text { Project scale and the business scope during project operation are essential attributes to the } \\
\text { project profitability }\end{array}$ \\
\hline Effects on local economy & $\begin{array}{l}\text { A project should serve both the local economy and take advantage of the infrastructure in the } \\
\text { local economy to generate economic benefits }\end{array}$ \\
\hline Life cycle cost analysis & $\begin{array}{l}\text { Analysis should not be given to elementary but total cost for building-up, operating, main- } \\
\text { taining, and disposing a construction project over its life }\end{array}$ \\
\hline Life cycle profit analysis & $\begin{array}{l}\text { Analysis should not be focused on stage or sectional profits but the total profit from opera- } \\
\text { ting a construction project across its life cycle }\end{array}$ \\
\hline Capital budget & Capital budget should be defined to planning and controlling project total cost \\
\hline Finance plan & $\begin{array}{l}\text { Defining and planning project finance schedule, for example, when, how, and how much to } \\
\text { finance }\end{array}$ \\
\hline Investment plan & $\begin{array}{l}\text { Arrangement of fixed and liquid capital for investment, and a cash flow plan at project } \\
\text { inception stage }\end{array}$ \\
\hline \multicolumn{2}{|l|}{ SSF-I } \\
\hline Land use & $\begin{array}{l}\text { Considering that the land selection for project site should protect cropland and natural } \\
\text { resources }\end{array}$ \\
\hline $\begin{array}{l}\text { Conservation of cultural and natu- } \\
\text { ral heritage }\end{array}$ & Avoiding negative impacts from project development on any cultural heritage \\
\hline Employment & Project implementation should be able to provide local employment opportunities \\
\hline Infrastructure capacity-building & $\begin{array}{l}\text { The project improves local infrastructure capacity, such as drainage, sewage, power, road, } \\
\text { and communication, transportation, dining, recreation, shopping, education, financing, and } \\
\text { medical }\end{array}$ \\
\hline Community amenities & $\begin{array}{l}\text { Provision of community amenities for the harmonization of new settlements and local com- } \\
\text { munities }\end{array}$ \\
\hline Safety assessment & $\begin{array}{l}\text { Assessment should be conducted to identify any future safety risks to the public and project } \\
\text { users }\end{array}$ \\
\hline \multicolumn{2}{|l|}{ EnSF-I } \\
\hline Eco-environmental sensitivity & $\begin{array}{l}\text { Avoiding as much as possible the irretrievable impacts on the surroundings from implemen- } \\
\text { ting a project }\end{array}$ \\
\hline Ecological assessment & Examining potential ecological risks and benefits associated with the proposed project \\
\hline Air assessment & $\begin{array}{l}\text { Examining potential air pollution from the proposed project and its impact on the local cli- } \\
\text { mate }\end{array}$ \\
\hline Water assessment & $\begin{array}{l}\text { Examining potential water pollution from the proposed project, including both surface and } \\
\text { ground water, and project's consumption on water resources }\end{array}$ \\
\hline Noise assessment & Examining potential noise pollution during both project construction and operation stages \\
\hline Waste assessment & Examining waste generation at both project construction and operation stages \\
\hline
\end{tabular}


Continued Table 2

\begin{tabular}{l|l}
\hline \multicolumn{2}{l}{ Project design stage } \\
\hline ESF-II & $\begin{array}{l}\text { Consider the total cost involved in project life cycle, including site formation, construction, } \\
\text { operation, maintenance cost and demolition cost }\end{array}$ \\
\hline Consideration of life cycle cost & Consideration being given to standard dimension in design specifications \\
\hline Project layout & Consideration being given to economy, durability and availability for material selection \\
\hline Materials choice & \multicolumn{2}{l}{ SSF-II } & $\begin{array}{l}\text { Considerations are given in designing process for emergencies such as fire, earthquake, } \\
\text { flood, radiation, and eco-environmental accidents }\end{array}$ \\
\hline Safety design & Installation of security alarm and security screen \\
\hline Security consideration & Knowledgeable of energy savings and environmental issues \\
\hline EnSF-II & $\begin{array}{l}\text { Effective communications among designers, clients, environmental professionals, and rele- } \\
\text { vant governmental staff to ensure all environmental requirements are incorporated into the } \\
\text { design process }\end{array}$ \\
\hline Designer & $\begin{array}{l}\text { Incorporation of all environmental considerations into project design for construction, opera- } \\
\text { tion, demolition, recycling, and disposal }\end{array}$ \\
\hline Life cycle design & $\begin{array}{l}\text { Use of modular and standardised components to enhance buildability and to reduce waste } \\
\text { generation }\end{array}$ \\
\hline Environmentally conscious design
\end{tabular}

\begin{tabular}{|c|c|}
\hline \multicolumn{2}{|l|}{ Project construction stage } \\
\hline \multicolumn{2}{|l|}{ ESF-III } \\
\hline Loan interests & $\begin{array}{l}\text { Consideration given to the interests for the capital cost paid for both a fixed loan and liquid } \\
\text { capital }\end{array}$ \\
\hline Opportunity cost & $\begin{array}{l}\text { Fixed and liquid capital tied up to project will loose opportunities of investing in other pro- } \\
\text { jects }\end{array}$ \\
\hline Labour cost & $\begin{array}{l}\text { Salaries paid to human resources, such as general construction workers, plumbers, pipe- } \\
\text { liners, carpenters, stonemasons, and bricklayers }\end{array}$ \\
\hline Professional fees & $\begin{array}{l}\text { Fees paid to various professionals and consultants such as engineers, environmental, ecolo- } \\
\text { gical, geological, and legal experts }\end{array}$ \\
\hline Materials cost & Costs for all types of materials such as concrete, lime, steel, timber, bamboo, and brick \\
\hline Energy cost & Costs for consuming various types of energy such as electricity, oil, gas, and coal \\
\hline Water cost & Costs for using water resources and for dealing with surface water, and ground water \\
\hline Equipment cost & Costs for using various tools, vehicles, and tower cranes \\
\hline Equipment purchase cost & $\begin{array}{l}\text { Costs for purchasing various equipment such as plants, elevators, escalators, and HVAC } \\
\text { systems }\end{array}$ \\
\hline Installation cost & Costs for the installation of all kinds of equipment and facilities \\
\hline Site security & Various types of measures for protecting the site safety \\
\hline \multicolumn{2}{|l|}{ SSF-III } \\
\hline Direct employment & $\begin{array}{l}\text { Provisions of working opportunities from implementing the project to the local labour mar- } \\
\text { ket, including construction workers, professionals, and engineers }\end{array}$ \\
\hline Indirect employment & Employment generated by the up-and-down stream industries and services to construction \\
\hline Construction safety & Safety measures, facilities, and insurance for working staff \\
\hline Public safety & Provision of warning boards and signal systems, safety measures and facilities for the public \\
\hline Improvement of infrastructure & Provisions of better drainage, sewage, road, message, heating, and electrical systems \\
\hline Infrastructure burden & Demand for water, road, energy, services and space for implementing the project \\
\hline \multicolumn{2}{|l|}{ EnSF-III } \\
\hline Land use pollution & Utilising land effectively and the measures taken to avoiding land pollution \\
\hline
\end{tabular}


Continued Table 2

\begin{tabular}{|c|c|}
\hline Natural habitat destruction & Protection of living environment for both human being and animals \\
\hline Air emission and pollution & Generation of $\mathrm{CO}_{2}, \mathrm{CO}, \mathrm{SO}_{2}, \mathrm{NO}_{2}$, and $\mathrm{NO}$ \\
\hline Noise pollution & Noise and vibration induced from project operation \\
\hline Discharges and water pollution & Release of chemical waste and organic pollutants to water ways \\
\hline Waste generation & Waste produced from project operation \\
\hline Comfort disturbance & Effects on people's living environment and the balance on eco-systems \\
\hline Energy and resource consumption & Saving energy and resources consumption including electrical, water and resources \\
\hline Health and safety risks & $\begin{array}{l}\text { Ensure on-site health and safety by reducing the number of accidents, providing on-site } \\
\text { supervision, and providing training programs to employees }\end{array}$ \\
\hline Using renewable materials & $\begin{array}{l}\text { Using typical renewable materials such as bamboo, cork, fast-growing poplar, and wheat } \\
\text { straw cabinetry, which are reproducible }\end{array}$ \\
\hline Ozone protection & $\begin{array}{l}\text { Reducing the release of chlorofluorocarbons and hydro-chlorofluorocarbons thus protecting } \\
\text { the onzone layer }\end{array}$ \\
\hline Off-site fabrication & Reducing on-site waste by using off-site fabrication \\
\hline Material reuse & Reuse of building components, rubble, earth, concrete, steel and timber \\
\hline Structural operations & $\begin{array}{l}\text { Consideration being given to the reduction of earthwork and excavation, formwork, reinfor- } \\
\text { cement, concreting and waste treatment during structural operation }\end{array}$ \\
\hline External and internal operations & $\begin{array}{l}\text { Controlling environmental impacts from walling, roofing, insulation, component installation, } \\
\text { plumbing and drainage, painting, landscaping, and waste treatment }\end{array}$ \\
\hline Health and safety & Emphasising on site hygiene, and the provision of health care and safety \\
\hline Project organisation & $\begin{array}{l}\text { Environmental management task force, resource coordination, supervision and cooperation } \\
\text { culture }\end{array}$ \\
\hline $\begin{array}{l}\text { Environmental management re- } \\
\text { sources }\end{array}$ & $\begin{array}{l}\text { Resource inputs for implementing environmental management, including labour, plant, ma- } \\
\text { terials and finance }\end{array}$ \\
\hline Organisational policy & $\begin{array}{l}\text { Establishment of environment management system, application of environmental manage- } \\
\text { ment standards such as ISO } 14000 \text {, project manuals, programs, progress control reports }\end{array}$ \\
\hline $\begin{array}{l}\text { Communication of environmental } \\
\text { management information }\end{array}$ & $\begin{array}{l}\text { Managing project environmental information through information management expertise and } \\
\text { information management facilities }\end{array}$ \\
\hline $\begin{array}{l}\text { Environmental management te- } \\
\text { chnology }\end{array}$ & $\begin{array}{l}\text { Environmental experts, environmental management facilities, energy and resource saving } \\
\text { technology, pollution reduction technology, and waste reduction technology }\end{array}$ \\
\hline Environmental regulations & Environmental protection law and regulations on construction activities \\
\hline \multicolumn{2}{|l|}{ Project operation stage } \\
\hline \multicolumn{2}{|l|}{ ESF-IV } \\
\hline Distribution of project income & Reinvestment, dividends, and paybacks \\
\hline Balance sheet from project operation & Develop a balance sheet to continuously check with the project cost and time \\
\hline Labour cost & Salaries for managerial staff, workers, professionals, and engineers \\
\hline General expenses & Daily water, electricity, gas, and consumables \\
\hline Materials cost & Various materials for project operation and maintenance \\
\hline Logistics costs & Materials procurement, stock costs, and transportation \\
\hline Marketing costs & Resource investment for market analysis, advertising, and promotion \\
\hline Training costs & Training employees for improving the quality of human resources \\
\hline $\begin{array}{l}\text { Improvement of local economic } \\
\text { environment }\end{array}$ & Consideration being given to benefit economically to the local society \\
\hline \multicolumn{2}{|l|}{ SSF-IV } \\
\hline $\begin{array}{l}\text { Direct employment in project } \\
\text { operation }\end{array}$ & Costs for employing workers, managers, and professionals \\
\hline Indirect employment & Employment associated with project operation along up-and-down stream industries \\
\hline
\end{tabular}


Continued Table 2

\begin{tabular}{l|l}
\hline Provision of services & Benefits of improving living standard to local communities \\
\hline Provision of facilities & Provision of spaces and facilities beneficial to the development of local communities \\
\hline EnSF-IV & Release of chemical wastes through dumping and landfills \\
\hline Land contamination & Generation of various chemicals such as $\mathrm{CO}_{2}, \mathrm{CO}, \mathrm{SO}_{2}, \mathrm{NO}_{2}$, and NO \\
\hline Air pollution & Release of chemical wastes and organic pollutants to water ways \\
\hline Water pollution & Noise and vibration induced from project operation \\
\hline Noise pollution & Wastes produced from project operations \\
\hline Waste generation & Negative impacts from project operations to flora, fauna, and ecosystems \\
\hline Ecological impacts & Energy consumption on electrical, lighting and other energy appliances \\
\hline Various energy consumption & Water usage for production of hygiene, cooling, and heating \\
\hline Water consumption & Use of both renewable and non-renewable raw materials \\
\hline Raw material consumption & Providing various education and training programs to different levels of employees \\
\hline $\begin{array}{l}\text { Environmental consciousness trai- } \\
\text { ning among employees }\end{array}$ & $\begin{array}{l}\text { Improving productivity, reducing the generation of pollution, and reducing resource con- } \\
\text { sumption }\end{array}$ \\
\hline $\begin{array}{l}\text { Environment friendly operation of } \\
\text { facilities }\end{array}$
\end{tabular}

\section{Project demolition stage}

ESF-V

\begin{tabular}{l}
\hline Labour cost \\
\hline $\begin{array}{l}\text { Energy consumed for operating } \\
\text { demolition }\end{array}$ \\
\hline Waste disposal costs \\
\hline Compensation to project stakeholders \\
\hline $\begin{array}{l}\text { Dissolution or deployment of pro- } \\
\text { ject staff }\end{array}$ \\
\hline $\begin{array}{l}\text { Compensation to the polluted envi- } \\
\text { ronment }\end{array}$ \\
\hline
\end{tabular}

\begin{tabular}{l|l}
\hline Land value for redevelopment & The \\
\hline Residual value & Val \\
\hline SSF-V &
\end{tabular}

\begin{tabular}{|c|c|}
\hline Land for new development & $\begin{array}{l}\text { Provision of land upon the completion of project demolition to enable implementing new } \\
\text { projects according to the demands of local community }\end{array}$ \\
\hline Job opportunity & Provision of jobs during project demolition for site work, transportation and disposal \\
\hline Operational safety & $\begin{array}{l}\text { Presence of safety risks to labors and the public during project demolition from explosion, } \\
\text { dismantling, toxic materials, and radioactive materials }\end{array}$ \\
\hline Communication to the public & Promotion on the public awareness of the project demolition and the possible impacts to the public \\
\hline \multicolumn{2}{|l|}{ EnSF-V } \\
\hline Demolition plan & Adequate demolition plan on hazard materials and waste reduction or recycle \\
\hline Demolition control & Supervision and control on the demolition activities to protect the environment \\
\hline $\begin{array}{l}\text { Environment-friendly demolition } \\
\text { method }\end{array}$ & $\begin{array}{l}\text { Adoption of technologies to alleviate the disturbance on eco-environment systems and nei- } \\
\text { ghbourhood, and to maximise waste reusing and recycling }\end{array}$ \\
\hline $\begin{array}{l}\text { Communication of environmental } \\
\text { information and policy }\end{array}$ & $\begin{array}{l}\text { Knowledge about environmental policies, regulations, legislations, and environmental } \\
\text { techniques }\end{array}$ \\
\hline Waste classification & Classification of demolition wastes for enabling effective treatment and disposal \\
\hline Special waste treatment & $\begin{array}{l}\text { Special treatment given to toxic materials, heavy metals, radioactive chemicals released from } \\
\text { demolition }\end{array}$ \\
\hline Waste recycling and reuse & Recycling and reclaiming of useful materials such as steel, brick, glass, timber, and some equipment \\
\hline
\end{tabular}

Human resources provided for planning, managing and operating project demolition

Crushing, transporting and relocating

Costs for waste loading and unloading, transportation, charges for disposals

Compensating to affected parties during demolition process

Provision of pensions, unemployment compensation

Compensation made for the damaged environment to the local residents, land, water, and ecosystems

The value of the land after demolition for re-development

Valuable residues, such as steel, brick, timber, glass, equipment for reuse and recycle

Provision of land upon the completion of project demolition to enable implementing new

Provision of jobs during project demolition for site work, transportation and disposal dismantling, toxic materials, and radioactive materials

Promotion on the public awareness of the project demolition and the possible impacts to the public

Adequate demolition plan on hazard materials and waste reduction or recycle

Supervision and control on the demolition activities to protect the environment

Adoption of technologies to alleviate the disturbance on eco-environment systems and neighbourhood, and to maximise waste reusing and recycling

Classification of demolition wastes for enabling effective treatment and disposal

Special treatment given to toxic materials, heavy metals, radioactive chemicals released from

Recycling and reclaiming of useful materials such as steel, brick, glass, timber, and some equipment 


\subsection{Design stage}

Design for construction projects is normally classified into preliminary design, technical design and shopdrawing design. The design stage presents the opportunity to consider the project sustainability performance in selecting its layout, structures and materials. Design process affects largely the project sustainability performance. For example, the design specifications affect functional performance of building components such as air conditioners, ventilation, lighting, electrical, heating, fire and water systems. Design specifications on project components should consider the project's economic, social and environmental performance across project life cycle.

\subsection{Construction stage}

The construction stage is to transfer the project design plans into reality. This process involves utilising various types of resources including human resources, equipment, materials, and financial resources. Many organisations are involved in this stage, including subcontractors, material suppliers, designers, consultants, thus management is presented with challenges of coordinating various project stakeholders to work towards common goals.

The construction stage is often described as including pre-construction and construction execution. During the pre-construction period, various subcontractors are recruited, construction materials and equipment are procured, and construction methods are planned in detail. During the construction execution period, various physical activities are undertaken according to design specifications, which involve utilisation of all types of resources including labour, construction equipment and materials. Activities during the construction stage have close association with environmental impacts such as waste generation and pollution.

\subsection{Operation stage}

Operation stage in a project's life cycle has major effects on project's sustainability performance. Good operation and management of the construction product can make contribution to the sustainability performance of the project, for example, by improving the operational efficiency, extending the service term, improving the social and economic profits, and mitigating the eco-environmental impacts. During project operation stage, feedbacks can be derived from continuous monitoring on the product operation through users such as the clients, end users, neighbours and local groups. Feedbacks should be seen as part of an integrated process aiming to achieve continuously the best sustainability performance. Furthermore, refurbishments will be undertaken during project operation in order to maintain the function of the product thus maintain its sustainability performance. A good plan for refurbishment can extend the service time and improve its operational efficiently, and thus enhance the sustainability performance of the project.

\subsection{Demolition stage}

Demolition of a construction product indicates the completion of the project's life, which will normally result in the generation of various wastes such as wood, concrete, metal, bricks, plastic, gypsum, roofing shingles, and glass. Practice suggests that the wastes from project demolition is far more than those from the construction process in a new project. Effective plans and management on project demolition can bring the lowest level of possible hazards, for example, by recycling as much as possible the dismantled materials along the material manufacturing chain.

\section{Conclusions}

This paper develops a project sustainability performance checklist applicable by all project participants to understand the major attributes affecting project sustainability performance in a consistent and holistic way across project life cycle. All processes across project life cycle carry the same importance to achieving better project sustainability performance. As project stakeholders such as governmental departments, clients, consultants, contractors, subcontractors and suppliers, have different extents to be involved in various project stages, usually individual parties focus on their own professions. The establishment of the sustainability performance checklist in this paper provides a tool that enable all parties to assess the sustainability performance of the project they are engaged across different stages including inception, design, construction, operation and demolition. Only all project stakeholders share the same information and knowledge of the project sustainability performance they can work together towards achieving better project performance. The use of the checklist will not only create a foundation of common understanding on key issues affecting project sustainability performance but also bring a "n-WINs" result among all participants through building up a better construction business environment.

However, the factor-checklists is by no means a definitive set but rather an introduction to a holistic and consistent approach. The approach is adaptable and needs to be applied with flexibility for assessing sustainability performance. For example, what is considered to be socially sustainable may not be sustainable in terms of economic sustainability. The procedure to assess sustainability performance is dynamic and affected by the interweaving factors. Further research is needed to investigate how to balance the factors to attain best sustainability performance by using a dynamic process.

\section{Acknowledgements}

This research was funded by the Hong Kong Research Grant Council, Hong Kong Special Administration Region, China. 


\section{References}

1. China State Environment Protection Bureau. China environmental state report in 1997: China State Environment Protection Bureau, Chinese Government, 1998.

2. DING, G.; LANGSTON, C. Multiple criteria sustainability modelling: case study on school buildings. International Journal of Construction Management, 2004, 4(2), p. 13-26.

3. GRIFFITH, A.; STEPHENSON, P.; BHUTTO, K. An integratal management system for construction quality, safety and environment: a framework for IMS. International Journal of Construction Management, 2005, 5(2), p. 51-60.

4. SJOSTROM, C,; BAKENS, W. Sustainable construction: why, how and what. Building Research and Information, 1999, 27(6), p. 347-353.

5. TSE, Y. C. R. The implementation of EMS in construction firms: case study in Hong Kong. Journal of Environmental Assessment Policy and Management, 2001, 3(2), p. 177-194.

6. World Commission on Environment and Developments. Our common future. Oxford: Oxford University Press, 1987.

7. SHEN, L. Y.; TAM, W. Y. V. Implementing of environmental management in the Hong Kong construction industry. International Journal of Project Management, 2002, 20(7), p. 535-543.

8. TAM, C. M.; TAM, W. Y. V; ZENG, S. X. Environmental performance evaluation for construction. Building Research and Information, 2002, 30(5), p. 349-361.

9. TAM, W. Y. V.; LE, K. N. Predicting environmental performance by using least-squares fitting method and robust method. Journal of Green Building, 2007. Accepted on 7 Nov 2006 (in press).

10. TAM, W. Y. V.; LE, K. N. The six-sigma principle and prevention-appraisal-failure modelling for quality improvement in construction. Building and Environment, 2007. Accepted on 29 June 2006 (in press).
11. TSE, O. P. A study on the attitude of workers to construction site safety in Hong Kong. Dept of Building and Real Estate, City Polytechnic of Hong Kong, 1994.

12. CHEN, Z.; LI, H.; WONG, T. C. Environmental management of urban construction projects in China. Journal of Construction Engineering and Management, 2000, 126(4), p. 320-324.

13. SHEN, L. Y.; WU, Y. Z.; CHAN, E. H. W.; HAO, J. L. Application of system dynamics for assessment of sustainable performance of construction projects. Journal of Zhejiang University Science, 2005, 6A(4), p. 339-349.

14 KIBERT, C. J. Establishing principles and a model for sustainable construction. In Proc of First International Conference of CIB TG 16 on Sustainable Construction. Tampa, Florida, USA, 1994, p. 3-12.

15. HILL, R. C.; BOWEN, P. Sustainable construction: principles and a framework for attainment. Construction Management and Economics, 1997, 15(3), p. 223-239.

16. SHEN, L. Y.; TAM, W. Y. V.; CHAN, C. W. S.; KONG, S. Y. J. An examination on the waste management practice in the local construction site. Hong Kong Surveyors, 2002, 13(1), p. 39-48.

17. TAM, W. Y. V.; TAM, C. M.; TSUI, W. S.; HO, C. M. Environmental indicators for environmental performance assessment in construction. Journal of Building and Construction Management, 2006 (in Press).

18. TAM, W. Y. V.; TAM, C. M.; ZENG, S. X.; CHAN, K. K. Environmental performance measurement indicators in construction. Building and Environment, 2005, 41(2), p. 164-173.

19. RIBA. Architectural practice and management. Royal Institute of British Architects. London, United Kingdom, 1973.

20. RITZ, G. J. Total construction project management. McGraw-Hill International Editions, 1994.

21. Building Services Research and Information Association. Environmental code of practice of buildings and their services: Bourne press Ltd, 1994.

\section{DARNAUS STATYBOS PROJEKTŲ VYKDYMO IVERTINIMO KATALOGAS}

\section{Y. Shen, J. L. Hao, Vivian W. Y. Tam, H. Yao}

Santrauka

Darnus statybų projektų vykdymas yra privalomas dalykas, norint pasiekti darnios plètros. Daugybė metodų ir valdymo igūdžių buvo išplètoti ankstesniuose tyrimuose siekiant pagerinti darnų darbų vykdymą realizuojamuose statybos projektuose. Tačiau šie metodai nebuvo sėkmingai pritaikyti dẻl didelio susiskaldymo ir prasto koordinavimo tarp skirtingų statybos projektų dalyvių. Jaučiamas trūkumas logiškų ir visa apimančių metodų, kurie padètų skirtingiems dalyviams igyvendinti darnios statybos praktiką ịvairiose projekto igyvendinimo stadijose. Šiame straipsnyje išplètota darnaus darbų vykdymo katalogo struktūra, kuri padès nustatyti pagrindinius veiksnius, darančius poveiki darniam statybos projektų igyvendinimui jų gyvavimo cikluose. Ši katalogo struktūra leidžia visas projekto šalis įvertinti projekto vykdymo darnumą logišku ir visa apimančiu būdu, taip pat ji gerina šalių bendradarbiavimą, skatina siekti darnaus projektų igyvendinimo.

Reikšminiai žodžiai: darni plètra, statyba, katalogas, darnus projektų igyvendinimas, projekto gyvavimo ciklai.

Li-Yin SHEN. Professor of construction management at the Dept of building \& real estate of the Hong Kong Polytechnic University. His major research interests are problems of sustainable construction, risk management for construction and real estate, and competitive strategy for construction business. He has published widely research works in international journals. Editor of an international journal on construction management. He has been leading the research group for sustainable development within a built environment. He has a number of external appointments including the president (founding president) of the Chinese research institute of construction management (1996-2000, 2005-2007), honorary Professor at deakin University of Australia (2007-2010), external examiner for the University of central Lancashire (2001-2005); visiting Professor at the University of Technology Malaysia. Member of American Society of Civil Engineers. 
Dr Jane, Jian Li HAO, received her BSc in Civil Engineering in China (1988) and PhD from the Hong Kong Polytechnic University (2002). Assistant Professor at the Dept of Building and Real Estate of the Hong Kong Polytechnic University. Her research interests include construction and demolition waste management, construction joint ventures, sustainability issues in construction process, and simulation application in construction.

Dr Vivian Wing-Yan TAM. Lecturer in the Griffith School of Engineering at the Griffith University (Australia). She maintained her PhD on sustainable construction at the Dept of Building and Construction in the City University of Hong Kong (2005). Her research interests are in the areas of environmental management in construction and sustainable development.

Hong YAO. PhD student at the Dept of Building and Real Estate, the Hong Kong Polytechnic University. YAO obtained her BEng in Industrial Engineering and Management and MEng in Management Engineering in P. R. China. She worked for China's local government and was a visiting scholar at the Schulich School of Business, York University, Canada. Her research interests are areas of sustainable construction and sustainability performance evaluation of construction projects. 